\title{
PEMBERDAYAAN PEREMPUAN MELALUI PELATIHAN PEMANFAATAN KAIN PERCA SEBAGAI AKSESORIS MELALUI MEDIA YOUTUBE DI LSM BENING SAGULING
}

\section{Tsaniatu Zakia}

Program Studi Pendidikan Masyarakat IKIP Siliwangi, Cimahi, Jawa Barat, Indonesia

tsaniareshe@gmail.com

Received: January, 2021; Accepted: January, 2021

\begin{abstract}
This research is motivated bye the large amount of spare time owned by housewives ehich has not been used optimally, but this free time is used to play smartphones. The purpose of this research is to describe in more detail about women's empowerment through training on the use of patchwork as accessories through Youtube media in Bening Saguling. This study uses a descriptive method with a qualitative approach, which is the subject of this study, one training Instructor and 10 housewives. While the data collection technique is by means of observation, interview and documentation. The result of this training is to provide patchwork skills for low-educated women, providing a skill that can be of personal use and of sale value. The benefits of this activity are that the work can be sold so that it is expected to be able to improve the standard of living of the community and fill women's spare time with more useful activities.
\end{abstract}

Keywords: Women's Empowerment, Training, YouTube

\begin{abstract}
Abstrak
Penelitian ini dilatar belakangi banyaknya waktu luang yang dimiliki Ibu-ibu rumah tangga yang belum bisa dimanfaatkan secara optimal, tetapi waktu luang tersebut digunakan untuk bermain smartphone. Tujuan dari penelitian ini yaitu untuk memaparkan lebih detail tentang pemberdayaan perempuan melalui pelatihan pemanfaatan Kain Perca sebagai Aksesoris melalui Media Youtube di Bening Saguling. Teori yang digunakan dalam penelitian ini yaitu Teori Pemberdayaan Perempuan, Teori Pelatihan dan Teori tentang Aplikasi Youtube. Penelitian ini menggunakan Metode Deskriptif dengan Pendekatan Kualitatif, yang menjadi Subjek dari penelitian ini yaitu satu orang Instruktur Pelatihan dan ibu-ibu rumah tangga sebanyak 10 orang. Sedangkan Teknik Pengumpulan data dengan cara Observasi, Wawancara dan Dokumentasi. Hasil dari pelatihan ini adalah memberikan suatu keterampilan kain perca bagi kaum perempuan berpendidikan rendah, memberikan suatu keterampilan yang bisa bermanfaat secara pribadi dan memiliki nilai jual. Adapun manfaat kegiatan ini adalah hasil karya dapat dijual sehingga diharapkan mampu meningkatkan taraf hidup masyarakat dan mengisi waktu luang masyarakat perempuan dengan kegiatan yang lebih bermanfaat.
\end{abstract}

Kata Kunci: Pemberdayaan Perempuan, Pelatihan, Youtube

How to Cite: Zakia, T. (2021). Pemberdayaan Perempuan Melalui Pelatihan Pemanfaatan Kain Perca Sebagai Aksesoris Melalui Media Youtube Di LSM Bening Saguling. Comm-Edu (Community Education Journal) 4 (1), 23-28.

\section{PENDAHULUAN}

Di era globalisasi sekarang ini, peran perempuan tidak hanya sebatas mengurus dan mengatur rumah tangga serta mendidik anak di rumah. Oleh karena itu, perempuan harus memiliki keterampilan dan kemandirian untuk dapat mengembangkan potensi dirinya. Selanjutnya dengan pemberdayaan perempuan, pemerintah daerah telah melakukannya berdasarkan 
24 Zakia, Pemberdayaan Perempuan Melalui Pelatihan Pemanfaatan Kain Perca Sebagai Aksesoris Melalui Media YouTube Di Bening Saguling

Program Pembangunan Nasional (PROPERNAS) pada tahun 2000-2004 dalam Undangundang Nomor 25 Tahun 2000 bab VIII Program-program Pembangunan butir 3 tentang kedudukan dan peran perempuan, yaitu : (1) meningkatkan kedudukan dan peran perempuan dalam kehidupan berbangsa dan bernegara melalui kebijakan nasional yang diemban oleh lembaga yang mampu memperjuangkan terwujudnya kesetaraan dan keadilan gender, (2) meningkatkan kualitas peran dan kemandirian organisasi perempuan dengan tetap mempertahankan nilai persatuan dan kesatuan, (3) meningkatkan nilai historis perjuangan kaum perempuan dalam rangka melanjutkan usaha pemberdayaan perempuan serta kesejahteraan keluarga.

Pemberdayaan Perempuan menurut Aida Vitayala (2010, hal. 155) adalah "peningkatan hak, kewajiban, kedudukan, kemampuan, peran, kesempatan kemandirian, ketahanan mental, dan spiritual wanita sebagai bagian tak terpisahkan dari upaya peningkatan kualitas SDM". Pengertian tersebut menunjukan bahwa pemberdayaan perempuan merupakan suatu upaya untuk meningkatkan keterampilan yang dapat digunakan untuk memenuhi kebutuhannya.

Pelatihan sering merujuk pada cara untuk memperoleh pengetahuan dan keahlian sebagai sebuah hasil dari pembelajaran mengenai kejuruan atau keahlian praktis dan pengetahuan yang berhubungan dengan kompetensi-kompetensi yang berguna. Menurut Simamora (Kamil, 2012, p. 4), mengartikan "pelatihan sebagai serangkaian aktivitas yang dirancang untuk meningkatkan keahlian-keahlian, pengetahuan, pengalaman ataupun perubahan sikap seorang individu". Kegiatan pelatihan sangat terbuka lebar seiring dengan perkembangan teknologi yang semakin pesat. Perkembangan media massa pada era digital juga terasa terhubung dengan kegiatan masyarakat dalam mencari informasi. Menurut Setiadi (2016) perkembangan penggunaan media internet sebagai komunikasi menjadi semakin pesat setelah internet mulai dapat diakses melalui telepon seluler dan bahkan kemudian muncul istilah telepon pintar (Smartphone). Kecanggihan teknologi tersebut dapat memudahkan kita untuk mengakses segala sesuatu yang dapat dilihat melalui internet. Internet itu sendiri terdapat media sosial yang diantaranya adalah Aplikasi YouTube. Pemanfaatan youtube sebagai media pembelajaran dapat digunakan setiap saat tanpa dibatasi oleh ruang dan waktu dengan syarat komputer atau media presentasi terhubung dengan internet. Dengan banyak fungsinya tersebut masyarakat dapat menggunakannya untuk berbagai macam kegiatan, terutama yang menunjang kegiatan pelatihan pemanfaatan kain perca.

Berdasarkan pengamatan awal, kondisi perempuan di Desa Cihampelas didominasi oleh ibuibu rumah tangga. Kegiatan mereka sehari-hari hanya membersihkan rumah, mengurus anakanak dan memasak. Setelah pekerjaannya selesai, waktu luang yang ada hanya digunakan untuk berbincang-bincang bersama tetangga, menonton televisi atau bermain smartphone. Koneksi internet yang sudah ada di Desa Cihampelas juga menjadi pendukung perkembangan media online sehingga masyarakat dengan mudah dapat mengakses berbagai informasi melalui media online. Kemampuan ibu-ibu dalam mengaplikasikan smartphone juga cukup baik. Beberapa ibu-ibu telah mengenal berbagai media sosial yang memungkinkan mereka memperoleh informasi lebih luas. Namun, saat ini penggunaan media sosial online hanya sebatas untuk hiburan saja. Ibi-ibu di Desa Cihampelas belum mampu memanfaatkan media online untuk menambah pengetahuan dan keterampilan yang dapat meningkatkan ekonomi keluarga.

Dengan demikian, penggunaan media online sebagai sarana pemberdayaan perlu dilakukan agar ibu-ibu rumah tangga dapat memanfaatkan waktu luangnya secara optimal dengan 
meningkatkan pengetahuan, keterampilan dan kreatifitasnya dalam menambah penghasilan keluarga. Berdasarkan uraian tersebut, maka peneliti memfokuskan penelitian pada judul "Pemberdayaan Perempuan Melalui Pelatihan Pemanfaatan Kain Perca Sebagai Aksesoris Melalui Media YouTube Di Bening Saguling".

\section{LANDASAN TEORI}

\section{Pemberdayaan Perempuan}

Secara etimologis pemberdayaan berasal dari kata dasar "daya" yang berarti kekuatan atau kemampuan. Menurut Soleh (2014, hal. 6), Pemberdayaan pada dasarnya merupakan serangkaian aktivitas untuk memperkuat dan atau mengoptimalkan daya diri suatu kelompok sasaran, yaitu masyarakat yang kurang berdaya.

Sedangkan Pemberdayaan Perempuan Menurut Novian (Latipah, 2020, hal. 3) adalah upaya perempuan-perempuan untuk memperoleh akses dan kontrol terhadap sumber daya, ekonomi, politik, social, budaya agar perempuan dapat mengatur diri dan meningkatkan rasa percaya diri untuk mampu berperan dan berpartisipasi aktif dalam memecahkan masalah, sehingga mampu membangun kemampuan dan konsep diri.

\section{Pelatihan}

Pelatihan sering merujuk pada cara untuk memperoleh pengetahuan dan keahlian sebagai sebuah hasil dari pembelajaran mengenai kejuruan atau keahlian praktis dan pengetahuan yang berhubungan dengan kompetensi-kompetensi yang berguna. Edwin B. flippo (Kamil, 2012, hal. 3) mengemukakan bahwa : "Training is the act of increasing the knowledge and skill of an employee for doing a particular job" (pelatihan adalah tindakan meningkatkan pengetahuan dan keterampilan seorang pegawai untuk melaksanakan pekerjaan tertentu). Sedangkan menurut Simamora (Kamil, 2012, hal. 4), mengartikan pelatihan sebagai serangkaian aktivitas yang dirancang untuk meningkatkan keahlian-keahlian, pengetahuan, pengalaman ataupun perubahan sikap seorang individu.

\section{Media YouTube}

Youtube yaitu sebuah social media yang mempublikasikan video, media ini dapat diakses oleh semua orang di negara manapun. Media ini resmi berdiri pada tahun 2005. Pendirinya yaitu Chad Hurley, Steve Chen, Jawed Karim, mereka bertiga ini adalah mantan karyawan PayPal. Kemudian media youtube dibeli oleh Google dan diperkenalkan kembali tahun 2006. Berdasarkan riset yang dilakukan oleh Hotsuite dalam (Putra, 2018), bahwa youtube sangat digemari oleh masyarakat Indonesia, dengan memasuki peringkat Most Active Social Media. Youtube sangat memudahkan masyarakat untuk menonton dan membagikan video untuk ditonton oleh masyarakat atau orang.

\section{METODE}

Dalam penelitian ini, peneliti menggunakan metode Deskriptif dengan Pendekatan Kualitatif. Alasan peneliti menggunakan pendekatan kualitatif deskriptif, karena permasalahan yang dibahas dalam penelitian ini tidak berpengaruh dengan angka-angka, akan tetapi menyangkut pendeskripsian, penguraian dan penggambaran suatu masalah yang sedang terjadi, yaitu proses pemberdayaan perempuan melalui pelatihan kain perca sebagai aksesoris. Pedekatan kualitatif menurut Sugiyono (2014), Penelitian Kualitatif adalah suatu prosedur penelitian yang menghasilkan data deskriptif, berupa data-data tertulis atau lisan dari orang-orang dan karakter yang dapat diamati sebagai objek penelitian. 
26 Zakia, Pemberdayaan Perempuan Melalui Pelatihan Pemanfaatan Kain Perca Sebagai Aksesoris Melalui Media YouTube Di Bening Saguling

Penelitian ini dilakukan di LSM Bening Saguling yang berada di Jl. Babakan Cianjur, Desa Cihampelas, Kec. Cihampelas Kab. Bandung Barat. Subjek Penelitian ini yaitu satu orang Instruktur pelatihan, dan Ibu-ibu rumah tangga sebanyak sepuluh orang dari jumlah keseluruhan 19 orang yang mengikuti pelatihan. Alasan peneliti mengambil sampel tersebut dikarenakan yang mengikuti pelatihan adalah ibu-ibu rumah tangga.

Instrumen penelitian yang digunakan oleh peneliti, yaitu Wawancara, Observasi, dan Dokumentasi. Adapun langkah-langkah yang ditempuh dalam analisis data kualitatif yaitu a) telaah data, b) reduksi data, c) penafsiran data dan penarikan kesimpulan..

\section{HASIL DAN PEMBAHASAN}

\section{Hasil}

Berdasarkan hasil wawancara dengan satu orang instruktur yang berinisial IN dan sepuluh orang ibu-ibu rumah tangga yang berinisial DW, SR, NJ, AR, YS, KM, NA, BA, ZL dan AS. Menurut Pendapat DW, SR dan NJ mengatakan bahwa baru pertama kali melakukan pelatihan pemanfaatan kain perca. Awalnya kami tidak tertarik untuk mengikuti kegiatan, cuman setelah melihat ibu-ibu yang lain pada ikut, kami juga pengen tau. Setelah kami mengikuti ternyata pelatihannya menggunakan aplikasi youtube, padahal yang kami tau youtubw itu hanya sebagai media hiburan saja. Alhamdulillah banyak pengetahuan yang kami dapatkan dari kegiatan pelatihan ini. Pendapat lain diungkapkan oleh AR, YS , KM dan NA mengatakan bahwa pelatihan menggunakan aplikasi youtube perlu disosialisasikan terlebih dahulu. Karena aktivitas kami membantu suami di sawah, jadi belum paham cara menggunakan ponsel bagus. Meskipun sering diajarkan sama anak, tapi maklum kami sudah agak tua jadi kurang dalam memahami penggunaan teknologi canggih. Tapi seiring berjalannya kegiatan pelatihan kami mulai mengerti bagaimana menggunakannya, apalagi kalau di rumah juga dibantu sama anak. Alhamdulillah kegiatan pelatihan ini sangat bermanfaat bagi kami. Lumayan untuk mengisi waktu luang. Begitupun pendapat BA, ZL dan AS yang mengatakan kegiatan ini manfaatnya untuk kami mulai dari pengetahuan dan keterampilan bisa kami dapatkan. Kegiatan ini dilaksanakan dengan memanfaatkan aplikasi youtube untuk pelatihan kain perca, kemudian di praktekan dengan instruktur dan yang lainnya. Selain itu juga kami diajarkan bagaimana memasarkan produk dari kain perca, alhamdulillah hasil penjualannya bisa membantu penghasilan keluarga. Pendapat tersebut diperkuat oleh IN selaku Intruktur kegiatan pelatihan yang mengatakan bahwa kegiatan pelatihan ini dimaksudkan untuk menambah pengetahuan dan keterampilan warga masyarakat dan semoga hasil dari pelatihan ini bisa dimaksimalkan dengan baik, selain itu ibu-ibu juga diberikan pengetahuan tentang bagaimana memasarkan produk dari kegiatan pelatihan supaya bisa menambah penghasilan untuk keluarga.

Berdasarkan pengamatan dilapangan, pelatihan dilakukan dengan memanfaatkan media youtube. Dimana pelatihan ini menggunakan video-video yang ada di YouTube sebagai sumber informasi bagi ibu-ibu. Kondisi awal pemahaman ibu-ibu dalam menggunakan media youtube masil belum maksimal. Mereka masih belum memahami bahwa youtube dapat memberikan berbagai informasi yang dibutuhkan, termasuk hal-hal yang diminati, sementara 
yang mereka ketahui bahwa youtube masih digunakan untuk melihat video-video hiburan. Seiring berjalannya kegiatan, ibu-ibu mulai menguasai materi-materi tentang kreasi kain perca melalui media youtube. Mereka telah mampu mengakses dan mengunduh berbagai video-video dari youtube, seperti jenis-jenis pemanfaatan kain perca, cara memasarkan produk dan yang lainnya. Video-video tersebut kemudian dijadikan sebagai referensi.

Pelatihan pemanfaatan kain perca sebagai aksesoris melalui media youtube diterima dengan baik dan proses pelatihannya berjalan dengan efektif dan efisien, serta ibu-ibu mulai memiliki penghasilan tambahan dari hasil pemanfaatan kain perca yang telah dijualnya. Namun ada beberapa kendala yang dihadapi instruktur dan ibu-ibu pada saat proses pelatihan, seperti ketersediaan akses internet dan besarnya biaya untuk membeli kuota.

\section{Pembahasan}

Pembahasan menguraikan hasil penelitian mengenai pemberdayaan perempuan melalui pelatihan pemanfaatan kain perca sebagai aksesoris melalui media Youtube di LSM Bening Saguling. Berdasarkan hasil penelitian, kegiatan pemberdayaan perempuan ini dimaksudkan untuk menambah pengetahuan dan keterampilan Ibu-ibu rumah tangga sekitar lingkungan LSM Bening Saguling. Menurut Riant Nugroho (2011, p. 164) mengemukakan Pemberdayaan Perempuan harus mampu meningkatkan kemampuan kaum perempuan dalam mengelola usaha skala rumah tangga, industri kecil maupun besar, untuk menunjang peningkatan kebutuhan rumah tangga, maupun untuk membuka peluang kerja produktif dan mandiri.

Pada observasi awal, pelaksanaan pemberdayaan perempuan dilakukan melalui kegiatan pelatihan langsung, yaitu pelatih memberikan dan mengajarkan keterampilan yang dimilikinya kepada ibu-ibu secara langsung. Selanjutnya, pelatihan dilakukan dengan memanfaatkan media youtube. Menurut Putra (2018), Youtube adalah situs web yang menyediakan berbagai macam video mulai dari video klip sampai film, serta video-video yang dibuat pengguna youtube sendiri. Pada kondisi awal, pemahaman ibu-ibu dalam menggunakan media youtube masih belum maksimal. Mereka masih belum memahami bahwa youtube dapat memberikan berbagai informasi yang dibutuhkan, termasuk hal-hal yang diminati, sementara yang mereka ketahui bahwa youtube masih digunakan untuk melihat video-video hiburan.

Pada observasi selanjutnya, ibu-ibu mulai terbiasa menggunakan media Youtube untuk bahan ajar pada pelatihan pemanfaatan kain perca. Pelaksanaan kegiatan pelatihan dilakukan dengan mengenalkan berbagai video yang berkaitan dengan kain perca. Kemudian menjelaskan cara-cara sederhana untuk mengunduh video-video tersebut dari youtube. Ibuibu kemudian dapat menentukan sendiri kreasi dari kain perca yang mereka minati dan dapat mengakses video-video yang berkaitan dengan cara pemasaran hasil kreasinya. Dengan demikian penggunaan media media youtube pada pelatihan pemanfaatan kain perca memberikan dampak positif bagi ibu-ibu yang mengikuti kegiatan pelatihan. Hal ini sesuai dengan pendapat yang dikemukakan oleh Kevin David B. Mangole (2017) bahwa Youtube bisa membawa dampak positif bagi penggunanya bila digunakan untuk mencari berbagai macam tutorial ataupun digunakan sebagai media pembelajaran.

Dari hasil wawancara yang diperkuat dengan hasil observasi mengenai pelatihan pemanfaatan kain perca melalui media youtube memiliki hambatan atau masalah saat pelaksanaan. 
28 Zakia, Pemberdayaan Perempuan Melalui Pelatihan Pemanfaatan Kain Perca Sebagai

Aksesoris Melalui Media YouTube Di Bening Saguling

Hambatannya adalah permasalahan jaringan data yang tersedia ketika mengakses aplikasi youtube sering kali tidak baik, tidak stabil, kemudian hambatan lain adalah ibu-ibu yangt ingin mengakses youtube terkendala dengan besarnya biaya membeli kuota data yang digunakan pada aplikasi youtube.

\section{KESIMPULAN}

Dari hasil wawancara yang diperkuat dengan hasil observasi yang dilakukan peneliti mengenai pemberdayaan masyarakat melalui pelatihan pemanfaatan kain perca melalui media youtube dapat disimpulkan sebagai berikut:

1. Pemahaman Ibu-ibu tentang penggunaan aplikasi youtube sudah mulai dimengerti dengan baik. Hal ini ditandai dengan seringnya ibu-ibu mengakses youtube untuk mendapatkan pengetahuan untuk meningkatkan keteranpilan mereka.

2. Pelatihan pemanfaatan kain perca melalui media youtube membawa dampak positif terhadap ibu-ibu. Hal ini dapat dapat dilihat saat kegiatan pelatihan berlangsung, ibu-ibu mengakses youtube untuk melihat video-video tentang tutorial pemanfaatan kain perca, jenis-jenis dan kreasi pada produk hasil pelatihan. Selain itu hasil penjualan produk dari hasil pemanfaatan kain perca dapat menambah pemasukan ekonomi keluarga.

3. Hambatan atau kendala yang sering terjadi pada saat mengakses youtube ketika pelatihan yaitu permasalahan jaringan data yang sering tidak stabil, ataupun putus-putus ketika melihat youtube, sehingga materi yang didapat tidak terlalu jelas. Kemudian kendala lainnya adalah permasalahan biaya kuota data yang cukup mahal untuk mengakses youtube tersebut.

\section{DAFTAR PUSTAKA}

Kamil, M. (2012). Model Pendidikan Dan Pelatihan. Bandung: Alfabeta.

Latipah, I. (2020). Pemberdayaan Perempuan Melalui Pemanfaatan Media Youtube dalam Meningkatkan Keterampilan Wirausaha. Jurnal COMM-EDU, 84.

Mangole, K. D. (2017). Pemanfaatan Youtube Dalam Meningkatkan Pengetahuan Masyarakat Di Desa Paslaten Kecamatan Remboken Minahasa. Journal Unsrat, 4(6), $1-15$.

Nugroho, R. (2011). Public Policy : Dinamika Kebijakan, Analisis Kebijakan, Manajemen Kebijakan. Jakarta: PT Elex Media Komputindo.

Putra, A. (2018). Pengaruh YouTube di Smart Phone terhadap Perkembangan Komunikasi Interpersonal Anak. Jurnal Penelitian Komunikasi, 161-162.

Setiadi, A. (2016). Pemanfaatan Media Sosial Untuk Efektifitas Komunikasi. Jurnal Humaniora, 2(16).

Soleh. (2014). Dialektika Pembangunan dengan Pemberdayaan. Bandung: Fokusmedia.

Sugiyono. (2014). Metode Penelitian Pendidikan Pendekatan Kuantitatif, Kualitatif, dan R\&D. Bandung: Alfabeta.

Vitayala, A. (2010). Pemberdayaan Perempuan dari Masa ke masa. Bogor: IPB Press. 